\title{
Editorial
}

\section{Quality in Endoscopy: It's Time for an Audit!}

\author{
Pedro Cardoso Figueiredo
}

Serviço de Gastrenterologia, Centro Hospitalar de Lisboa Ocidental, Lisbon, Portugal

Keywords

Quality·Colonoscopy·Performance measures

\section{Qualidade em Endoscopia: É Altura de Auditar!}

\section{Palavras Chave}

Qualidade $\cdot$ Colonoscopia $\cdot$ Indicadores de qualidade

Quality in endoscopy, particularly in colonoscopy, is in the spotlight with an increasing number of publications in recent years. Both the American and European societies have set numerous quality indicators or performance measures with which individuals or groups of individuals can compare themselves and assess the quality of the service they provide $[1,2]$. Of these, the adenoma detection rate has come forth as the most important measure of the quality of mucosal inspection during colonoscopy and has been validated as a predictor of cancer prevention by screening colonoscopy for colorectal cancer [3]. Perhaps not as measurable as cancer prevention but at least as important, high-quality colonoscopy may also provide better health outcomes, better patient experi-

\begin{tabular}{|c|c|}
\hline$A D C$ & iedade Portuguesa de $\mathrm{C}$ \\
\hline 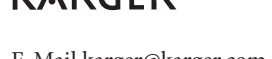 & $\begin{array}{l}\text { Karger } \\
\text { Open access }\end{array}$ \\
\hline wwy & $\begin{array}{l}\text { This article is licensed under the Creative Commons Attribution- } \\
\text { NonCommercial-NoDerivatives } 4.0 \text { International License (CC BY- } \\
\text { NC-ND) (http://www.karger.com/Services/OpenAccessLicense). } \\
\text { Usage and distribution for commercial purposes as well as any dis- } \\
\text { tribution of modified material requires written permission. }\end{array}$ \\
\hline
\end{tabular}

ence, and cost reduction [4]. Therefore, and taking into account that only approximately $30 \%$ of colonoscopies are for screening purposes, other quality indicators should not be overlooked [5]. Nevertheless, and despite growing attention, recent studies still report significant variation in the quality of endoscopy performed across different endoscopy units $[6,7]$. So, if on the one hand the importance of quality is known and there are guidelines providing endoscopists with benchmarks against which they can compare their service, but on the other hand significant variation in quality still persists, what should be done? Part of the answer is provided in this issue with the work by Taveira et al. [8], as well as in a previous issue [9]: an audit! Quality audits allow for identification of underperformance, providing both individual endoscopists and endoscopy units with an opportunity for discussion and implementation of strategies for improvement [4]. For instance, in their retrospective study, Taveira and colleagues found opportunities for improvement in their unit, namely by adopting a better scale for bowel preparation evaluation. Interestingly, the authors also adopted and proposed a minimum set of 8 pictures per exam (at least 3 photos for segmental documentation of bowel preparation, at least 2 photos to document the cecum and ileocecal valve, and 3 for documentation of findings and

Dr. Pedro Cardoso Figueiredo Serviço de Gastrenterologia Centro Hospitalar de Lisboa Ocidental, Hospital de Egas Moniz Rua da Junqueira 126, PT-1349-019 Lisbon (Portugal) E-Mail pedro.c.figueiredo@ hotmail.com 
other important landmarks). Current guidelines only emphasize the need for photodocumentation of the cecal landmarks $[1,2]$. The authors' proposal is a modification from an old guideline recommendation [10] and, although they recognized it as arbitrary, may serve useful as a corroboration of the reported segmental bowel preparation scale. There are several limitations in their study but perhaps the most important, which demands improvement, pertains to an unmet need in several (perhaps all) endoscopy units across the country: an adequate electronic endoscopy reporting system as recommended by ESGE guidelines [11]. One of these recommendations is the possibility for easy data retrieval, namely performance measures, and that might overcome one of the greatest hurdles to audits: current software makes them cumbersome and time-consuming. Nonetheless, audits should be performed regularly, if only because endoscopists may perform better while under monitoring (the Hawthorne effect). We owe it to our patients to deliver the highest quality in endoscopy, therefore all endoscopists and endoscopy units should ensure the implementation and monitoring of performance measures [12].

\section{Disclosure Statement}

The author reports no potential conflict of interest.

\section{References}

1 Kaminski MF, et al: Performance measures for lower gastrointestinal endoscopy: a European Society of Gastrointestinal Endoscopy (ESGE) Quality Improvement Initiative. Endoscopy 2017;49:378-397.

2 Rex DK, et al: Quality indicators for colonoscopy. Gastrointest Endosc 2015;81:31-53.

3 Rex DK, et al: Colorectal cancer screening: recommendations for physicians and patients from the U.S. Multi-Society Task Force on Colorectal Cancer. Gastrointest Endosc 2017; $86: 18-33$.

4 Rutter MD, Rees CJ: Quality in gastrointestinal endoscopy. Endoscopy 2014;46:526-528.

5 Peery AF, et al: Burden of gastrointestinal disease in the United States: 2012 update. Gastroenterology 2012;143:1179-1187.
6 Paggi S, et al: Pre-and post-procedural quality indicators for colonoscopy: a nationwide survey. Dig Liver Dis 2016;48:759-764.

7 Ranasinghe I, et al: Differences in colonoscopy quality among facilities: development of a post-colonoscopy risk-standardized rate of unplanned hospital visits. Gastroenterology 2016;150:103-113.

8 Taveira F, et al: Quality in colonoscopy: beyond the adenoma detection rate fever. GE Port J Gastroenterol 2017, DOI: 10.1159/ 000478940.

9 Ferreira AO, et al: Adenoma detection rate: I will show you mine if you show me yours. GE Port J Gastroenterol 2017;24:61-67.
10 Rey JF, Lambert R; ESGE Quality Assurance Committee: ESGE recommendations for quality control in gastrointestinal endoscopy: guidelines for image documentation in upper and lower GI endoscopy. Endoscopy 2001;33: 901-903.

11 Bretthauer M, et al: Requirements and standards facilitating quality improvement for reporting systems in gastrointestinal endoscopy: European Society of Gastrointestinal Endoscopy (ESGE) Position Statement. Endoscopy 2016;48:291-294.

12 Rutter MD, et al: The European Society of Gastrointestinal Endoscopy Quality Improvement Initiative: developing performance measures. Endoscopy 2016;48:81-89. 